1 Published as: Prave, A.R. et al. Geology and geochronology of the Tana Basin, Ethiopia: LIP 2 volcanism, super eruptions and Eocene-Oligocene environmental change. Earth Planet. Sci. 3 Lett. (2016) http://10.1016/j.epsl.2016.03.009

\title{
Geology and geochronology of the Tana Basin, Ethiopia: LIP volcanism, super eruptions and Eocene-Oligocene environmental change
}

A.R. Prave ${ }^{1 *}$, C.R. Bates ${ }^{1}$, C.H. Donaldson ${ }^{1}$, H. Toland ${ }^{2}$, D.J. Condon ${ }^{3}$, D. Mark ${ }^{4}$, T.D. Raub ${ }^{1}$

${ }^{1}$ Department Earth and Environmental Sciences, University of St Andrews, KY16 9AL, UK

${ }^{2}$ Department Geography and Earth Sciences, Aberystwyth University, Wales, SY23 3DB

${ }^{3}$ NERC Isotope Geosciences Laboratory, BGS, Keyworth, NG12 5GG, UK

${ }^{4}$ Isotope Geoscience Unit, Scottish Universities Environmental Research Centre, East Kilbride, G75 0QF, UK

*corresponding author: email ap13@st-andrews.ac.uk

\section{Abstract}

New geological and geochronological data define four episodes of volcanism for the Lake Tana region in the northern Ethiopian portion of the Afro-Arabian Large Igneous Province (LIP): pre-31 Ma flood basalt that yielded a single ${ }^{40} \mathrm{Ar} /{ }^{39} \mathrm{Ar}$ age of 34.05 $\pm 0.54 / 0.56 \mathrm{Ma}$; thick and extensive felsic ignimbrites and rhyolites (minimum volume of 2-3 x 10 $\mathrm{km}^{3}$ ) erupted between $31.108 \pm 0.020 / 0.041 \mathrm{Ma}$ and $30.844 \pm 0.027 / 0.046 \mathrm{Ma}$ (U-Pb CA-ID-TIMS zircon ages); mafic volcanism bracketed by ${ }^{40} \mathrm{Ar} /{ }^{39} \mathrm{Ar}$ ages of 28.90 $\pm 0.12 / 0.14 \mathrm{Ma}$ and $23.75 \pm 0.02 / 0.04 \mathrm{Ma}$; and localised scoraceous basalt with an ${ }^{40} \mathrm{Ar} /{ }^{39} \mathrm{Ar}$ age of $0.033 \pm 0.005 / 0.005 \mathrm{Ma}$. The felsic volcanism was the product of super eruptions that created a 60-80 km diameter caldera marked by km-scale caldera-collapse fault blocks and a steep-sided basin filled with a minimum of $180 \mathrm{~m}$ of sediment and the present-day Lake Tana. These new data enable mapping, with a finer resolution than previously possible, Afro-Arabian LIP volcanism onto the timeline of the EoceneOligocene transition and show that neither the mafic nor silicic volcanism coincides directly with perturbations in the geochemical records that span that transition. Our results reinforce the view that it is not the development of a LIP alone but its rate of effusion that contributes to inducing global-scale environmental change.

Keywords: LIP, Eocene-Oligocene transition, Lake Tana, flood basalt, super eruption

\section{Introduction}

Temporal coincidence between Large Igneous Provinces (LIPs) and worldwide environmental perturbation is often considered evidence for causality (e.g. Bond \& 
and 0.35-1.0 x $10^{6} \mathrm{~km}^{3}$ (Mohr and Zanettin 1988; Dessert et al. 2003), seemingly had little influence on Cenozoic climate (Hofmann et al. 1997; Rochette et al. 1998; Ukstins Peate et al. 2003). Here we present new geological and geochronological data that provide a refined understanding of the development of that LIP and its temporal relationship to the climatic events of the Eocene-Oligocene transition.

1.1. Geological background. The Ethiopian Highlands are a volcanic massif of flood and shield volcano basalt 0.5 to $3 \mathrm{~km}$ thick that form spectacular trap topography (1500 to 4500 m altitudes) flanking the Main Ethiopian Rift (Fig. 1; Mohr 1983). Volcanic activity was protracted but episodic: flood basalt at 31-29 Ma, shield volcanoes at 30-19 and 12$10 \mathrm{Ma}$, felsic volcanism at 30-25, 20-15 and 12-3 Ma, and Pliocene-Quaternary basalt (Hofmann et al. 1997; Pik et al. 1998; Rochette et al. 1998; Ayalew et al. 2002; Ukstins et al. 2002; Coulié et al. 2003; Riisager et al. 2005). In the midst of the massif is a $16,500 \mathrm{~km}^{2}$ topographic depression that contains Lake Tana, the source of the Blue Nile and Ethiopia's largest lake with a diameter of 60-80 km. The dominant rock type in the Tana region is low-Ti tholeiitic Miocene-Pliocene basalt and lesser amounts of felsites and nonmarine sedimentary rocks and locally restricted basalt cinder cones and flows (Pik et al. 1998; Abate et al. 1998; Ayalew et al. 2002). Our petrological findings echo those of previous workers and show that compositions are bimodal: sub- to mildly alkaline (Mg0 5.0-9.5 wt\%) olivine- to plagioclase-phyric basalt, and dacites to rhyolites including banded finely crystalline to glassy rocks, crystal \pm lithic \pm vitric tuffs, obsidian-rich agglomerates and coarse ignimbrites.

\section{Results: new geological data}

Our mapping defined five major units (Figs. 2 and 3). Flood basalt, with a base at $\sim 700$ m elevation and its top at $\sim 1600 \mathrm{~m}$. An overlying unit, many tens to several hundreds of metres thick, of flow-banded rhyolite, pumice/lithic-rich and -poor tuffs, coarse-grained silicic ignimbrites, volcanic breccias and epiclastic sandstone and agglomerate (Fig. 4); clast sizes range from lapilli to bombs several metres in diameter. The felsic rocks occur in fault blocks hundreds of metres in width, 0.2 to $3 \mathrm{~km}$ in length and arranged centroclinally (dip generally inward) around the lake (Fig. 5a) although areas north and east of the lake exhibit a more jumbled fault pattern relative to southern and western areas. The fault blocks are present only within several tens of kilometres of Lake Tana 
but the felsic rocks extend well beyond the map area.

The third unit ("Chilga beds" of Yemane et al. 1987) is patchily preserved, several tens to at least two hundred metres thick, and consists of organic-rich to lignitic mudstone and fine- to coarse-grained sandstone, thin felsic tuffs and silicite beds, and interlayered sparsely olivine-phyric amygdaloidal (quartz- or calcite-filled) basalt and andesitic basalt. The sedimentary rocks are lacustrine and fluvial deposits, and contain fossil bone and plant material that, along with associated palynomorphs, indicate that climate then was much wetter than today's (Yemane et al. 1987).

The fourth unit is olivine- and/or plagioclase-phyric and vesicle-rich to -poor basalt that form 2-3 km high plateaux. Its base is an unconformity along which successive basalt flows onlap and bury an irregular palaeotopography formed on the felsic fault blocks (Fig. 5b) and sedimentary-basalt unit ("Chilga beds"). Thick but variably developed kaoliniterich weathering profiles beneath the unconformity surface indicate a substantial hiatus prior to the initial outpouring of the basalt forming the high plateaux. The fifth unit is scoraceous basalt and cinder cones in areas south of Lake Tana.

Our geophysical surveys show that Lake Tana overlies a basin marked by subvertical walls and filled with at least $180 \mathrm{~m}$ of flat-lying sediment (Fig. 6). The timing of sedimentation remains to be determined but linear extrapolation using a ${ }^{14} \mathrm{C}$ age of $\sim 17$ ka obtained at $10.2 \mathrm{~m}$ depth in a $90 \mathrm{~m}$ core through those sediments (Marshall et al. 2011) suggests that the base of the core is in excess of $150 \mathrm{ka}$. In effect, Tana is a steep-sided bowl filled with thick flat-lying sediments whose ultimate age is unknown but predate the scoraceous basalts that form the present-day dam and outflow of the lake.

2.1. Caldera-forming super eruptions. Previous workers interpreted the Tana basin as a consequence of the confluence of three rift structures (e.g. Chorowicz et al. 1998). Our new data suggest that it is a caldera: the centroclinal fault blocks decrease in magnitude (over distances of tens of kilometres) away from the lake and pre-date the unconformably overlying sedimentary-basalt ("Chilga beds") and plateaux-forming basalt units thus are unrelated to the younger high-angle, largely dip-slip faults that transect all the rock units in the Tana basin and which are part of the Neogene opening of the Main Ethiopia Rift. Further, the ignimbrites and associated felsic rocks are thickest and coarsest adjacent to Tana and thin and fine in all directions away from the lake. These rocks cover at least $10,000 \mathrm{~km}^{2}$ but extend far beyond the map area and average 200-300 $\mathrm{m}$ in thickness 
hence their minimum eruptive volume would have been $2000-3000 \mathrm{~km}^{3}$. These are characteristics of super eruptions (e.g. Bryan and Ferrari 2013) and jointly with the seismic data underpin our interpretation that Tana is a caldera ringed by fault blocks formed by caldera collapse. Today's landscape reflects this ancient caldera exhumed by head-ward erosion of the Blue Nile River system.

\section{Results: new geochronology data}

Our geochronology strategy was designed to constrain the timing of emplacement of the felsic unit, determine the ages of the basalts bounding that unit and define the age of the basalts that dam the outflow of the present-day lake (Figs. 2 and 3). Dates are shown with two levels of uncertainty $( \pm A / B)$ where $A$ is the analytical uncertainty and $B$ is the analytical uncertainty combined with systematic uncertainties related to calibration and decay constants; details of the samples, dating methodologies and analytical results can be found in the Supplemental Files.

Age constraints for the felsic volcanism are from zircons separated from four samples and analysed at the NERC Isotope Geoscience Laboratory, UK, using U-Pb chemical abrasion-isotope dilution-thermal ionisation mass spectrometry (CA-ID-TIMS); all samples were spiked using the gravimetrically calibrated ET535 or ET2535 EARTHTIME U-Pb tracer solutions (Condon et al. 2015; McLean et al. 2015; see Supplemental Files). Constraints for the mafic volcanism are by ${ }^{40} \mathrm{Ar} /{ }^{39} \mathrm{Ar}$ analyses on four samples done at the NERC Argon Isotope Facility, UK, following methods outlined in Mark et al. 2010 (see Supplemental Files).

3.1. Felsic samples. Sample Hydro- 1 is a lapilli tuff near the base of the felsite unit $\sim 7$ $\mathrm{km}$ southwest of Kunzla; four zircons were analysed and yield a mean age of 31.108 $\pm 0.020 / 0.041 \mathrm{Ma}$. Sample Zege-1 is a flow-banded stony rhyolite in the central part of the felsite unit exposed in an erosional window through Quaternary basalt $\sim 7 \mathrm{~km}$ west of Bahir Dar; four zircons were analysed and yield a mean age of $31.033 \pm 0.018 / 0.041$ Ma. Samples Yifag-2 and Aby-1 are flow-banded feldspar-phyric rhyolites from the upper part of the felsite unit $\sim 1.5$ and $1 \mathrm{~km}$ west of Yifag, respectively; five zircons from each were analysed and yield mean ages of $30.858 \pm 0.024 / 0.044 \mathrm{Ma}$ and $30.844 \pm 0.027 / 0.046$ Ma, respectively. 
3.2. Mafic samples. All mafic samples are olivine- and/or plagioclase-phyric basalt.

140 Sample BNG1 was collected near the top of the lower flood basalt $\sim 0.5 \mathrm{~km}$ southeast of

141 the Blue Nile Falls and yielded a total fusion age of 34.05 $\pm 0.54 / 0.56$ Ma. Sample WD1 is

142 from the sedimentary-basalt unit $\sim 8 \mathrm{~km}$ west of Aykel and yielded a plateau age of 28.90

$143 \pm 0.12 / 0.14 \mathrm{Ma}$. Sample KNZ1 is from the lower part of the upper basalt unit $\sim 3 \mathrm{~km}$ south 144 of Kunzla and yielded a plateau age of $23.75 \pm 0.02 / 0.04$ Ma. Sample BHD1 is from the 145 outflow of the Blue Nile River in Bahir Dar and yielded a plateau age of 0.033 $146 \pm 0.005 / 0.005 \mathrm{Ma}$.

3.3. Geochronology summary. The new geochronology defines four distinct episodes of volcanism: (i) $\sim 1 \mathrm{~km}$ thick flood basalt likely as old as $\sim 34$ Ma but of unknown duration; (ii) caldera-forming silicic super eruptions at $\sim 31$ Ma spanning $\sim 250 \mathrm{kyr}$ with a minimum erupted volume of $2000-3000 \mathrm{~km}^{3}$; (iii) a second episode of mafic volcanism starting perhaps as early as $\sim 29 \mathrm{Ma}$ and extending to at least $\sim 24 \mathrm{Ma}$; and (iv) localised basalt flows and cinder cones $33 \mathrm{ka}$ in age. The $34 \mathrm{Ma}$ age is older than the 31-29 Ma ages typically attributed to Ethiopian flood basalt (Hofmann et al. 1997; Rochette et al. 1998) and, even if that age is downplayed, this flood basalt can be no younger than the c. $31 \mathrm{Ma}$ age of the overlying felsic rocks and hence older than most previously documented AfroArabian flood basalt. Determining if these phases are distinct requires further geochronology and mapping.

\section{Discussion: Tana volcanism and Eocene-Oligocene environmental change}

Stable isotope and organic geochemistry trends for the Cenozoic define one of the finest timelines of global change for anytime in Earth history (Fig. 7). Our new data permit a stricter evaluation than previously possible of Afro-Arabian LIP volcanism to those data.

4.1. Atmospheric $\mathrm{CO}_{2}$ drawdown and $\mathrm{C}-\mathrm{O}$ isotopes. Following a zenith of global warmth at $\sim 55$ Ma climate underwent a descent into the current state of bipolar icecaps (e.g. Zachos et al. 2001; Pälike et al 2006). The late Eocene-early Oligocene receives particular attention because of temporally distinct, sharp steps in C-O isotopes ( 11.5\%, e.g. Oi1 and Oi-2 on Fig. 7; e.g. Miller et al. 1991; Coxall \& Wilson 2011 and references therein) and declines in atmospheric $\mathrm{CO}_{2}$ ( $\sim 300-500$ ppm; e.g. Zhang et al. 
estimated to be between several $10^{4}$ and $10^{5}$ years.

LIP emissions can generate global warming but can also cause global cooling due to drawdown of those gases via weathering of fresh basalt. The Afro-Arabian LIP comprises $\sim 13 \%$ of today's exposed basalt but only accounts for $\sim 4 \%$ of the annual flux of $\mathrm{CO}_{2}$ drawdown because of its arid setting (Dessert et al. 2003). However, that region's climate was much wetter during the Oligo-Miocene (e.g. Yemane et al. 1987) and, although no quantitative estimates exist for how much wetter, the then rate of consumption of atmospheric $\mathrm{CO}_{2}$ of fresh basalt would have been higher than today's.

A back-of-the-envelope calculation can be undertaken to assess what the potential effect of the Tana eruptions might have been on atmospheric $\mathrm{CO}_{2}$ drawdown, and we make two assumptions: (i) that the present-day preserved outcrop area of the AfroArabian LIP approximates the original extent of flood basalt; and (ii) a flux of $4 \times 10^{12}$ $\mathrm{molCO}_{2}$ /year, representative of today's other low-latitude flood basalt provinces (Parana, Deccan, Central American; Dessert et al. 2003), is a reasonable approximation for the weathering of those basalts during Palaeogene time. The latter assumption is justifiable because fossil evidence indicates relatively high precipitation during emplacement of the Afro-Arabian LIP, which has 30-50\% more surface area than those provinces. Further, estimates of globally averaged $\mathrm{CO}_{2}$ consumption by basalt weathering vary by $\sim 4 \mathrm{x}$, from $1.75 \times 10^{13} \mathrm{molCO}_{2}$ /year (Navarre-Stichler and Brantley 2007) to $4.08 \times 10^{12}$ molCO 2 /year (Dessert et al. 2003) hence the chosen flux is a reasonable estimate. Depending on estimates of atmospheric composition, $1 \mathrm{ppm}$ of atmospheric $\mathrm{CO}_{2}$ equates to between $\sim 3$ to $7.8 \mathrm{Gt}$. Generating the stepwise decreases of $300-500 \mathrm{ppm} \mathrm{CO}_{2}$ would have required drawing down 2300-3900 Gt. Simplifying the calculation to focus solely on weathering, a time-averaged flux of $4 \times 10^{12} \mathrm{molCO}_{2} /$ year would have drawn-down $\sim 0.02$ $\mathrm{GtCO}_{2}$ /year, requiring $\sim 50-200 \mathrm{kyr}$ to generate the estimated magnitude of change indicated by each of the step-wise declines of $\mathrm{CO}_{2}$. Volcanic degassing and/or cryptic degassing (Armstrong Mckay et al. 2014) would have acted to reduce the declines but, given the worldwide cooling trend at that time, that influence must have been minimal.

This thought experiment shows that a rate of weathering-induced $\mathrm{CO}_{2}$ drawdown can be obtained that is compatible with that implied by previous workers for the two drops in Eocene-Oligocene $\mathrm{CO}_{2}$. However, mapping our geochronological data onto the timeline of Eocene-Oligocene environmental change (Fig. 7) refutes that possibility. Assuming that (i) the c. $10^{4-5}$ year estimated durations required to drawdown $\mathrm{CO}_{2}$ are 
correct to within an order-of-magnitude and (ii) the absolute ages of those drawdowns based on the proxy records are broadly correct, then the c. 34 Ma episode of flood basalt predates by at least $0.5-1 \mathrm{Myr}$ the proposed timing of the earlier drop in atmospheric $\mathrm{CO}_{2}$ that began prior to the Eocene-Oligocene boundary (Fig. 7). Further, the second drop in $\mathrm{CO}_{2}$ occurred $\sim 3 \mathrm{Myr}$ after the c. $29 \mathrm{Ma}$ onset of the younger phase of mafic volcanism. The modelled $p \mathrm{CO}_{2}$ data over that time are, within error, largely invariant for 3-4 Myr through the outpouring of the c. 34-31 Ma flood basalt and c. 31 Ma silicic eruptions, yet show a slight increase during the apparent gap in volcanic activity in the Tana region. Thus, there is a temporal disconnect between the timing of volcanic activity and the pattern of $\mathrm{CO}_{2}$ fluctuations indicated by the proxy data records (Fig. 7). Although weathering of the Afro-Arabian basalts no doubt contributed to long-term $\mathrm{CO}_{2}$ drawdown (e.g. Lefebvre et al. 2013; Kent \& Muttoni 2013), our findings rule out volcanism as a key influence on the shorter-term, $10^{4-5}$ year draw-down timescales implied by the various $\mathrm{CO}_{2}$ proxy data.

Our geochronology also reveals that there is no consistent relationship between the trend of $\mathrm{O}$ - and $\mathrm{C}$-isotopes and the timing of mafic volcanism. $\mathrm{O}$ isotopes increase, and sharply so (i.e. at Oi-1, Fig. 7), entering the c. 34-31 Ma phase of volcanism but maintain a broadly invariant trend throughout that phase. In contrast, 0-isotopes remain unperturbed across the initiation of the c. 29 Ma phase of mafic volcanism, reach a zenith (marked by 0i-2; Fig. 7) several millions of years after that onset, and then decline throughout the remaining phase of volcanic activity. We do not know the exact timing of onset of the pre-31 Ma flood basalt, and it is tempting to consider a possible link to the sharp increase in slope in 0 isotopes at the Eocene-Oligocene transition, but additional geochronology is needed to test this plausibility. The C-isotope profile also shows contrary relationships between volcanic episodes: $\mathrm{C}$ isotopes rise irregularly and then fall steadily through the c. 34-31 Ma phase of mafic volcanism, are unperturbed during the c. 31 Ma super eruptions, and rise irregularly through the c. 29-23 Ma phase of mafic volcanism. Thus, the c. 34-23 Myr span of Afro-Arabian LIP volcanism in the Tana region failed to imprint significantly on the isotopic compositions of the Eocene-Oligocene oceans and atmosphere.

4.2. Volatiles as kill mechanisms. The rate and magnitude of injection of sulphur and halogen molecules into the atmosphere from LIP volcanism has been highlighted as kill 
mechanisms for mass extinction especially when devolitalisation of evaporite- and organic-rich country rock occurs (e.g. Chenet et al. 2007; Svensen et al. 2009; Brand et al. 2012; Black et al. 2012). The Afro-Arabian LIP silicic volcanism released $\sim 45$ Gt $S$ and $\sim 224 \mathrm{Gt} \mathrm{Cl}$ (Ayalew et al. 2002), in part attributable to volatiles derived from the $1-2 \mathrm{~km}$ thick Mesozoic succession of which $\sim 50 \%$ consists of marine carbonate and evaporite rocks and minor lignites and coals (Wolela et al. 2008). No such estimates have been made for the mafic volcanism, but a first-order approximation for the potential amount of degassed volatiles from both the silicic and mafic lavas can be attempted. We make a supposition that the amounts of $\mathrm{S}$ and $\mathrm{Cl}$ devolitalised by both types of volcanism scaled proportionally to their respective volumes. The volume of basalt in the Afro-Arabian LIP is $\sim 6 \times 10^{4} \mathrm{~km}^{3}$, which is $5-15 \mathrm{x}$ the total volume that has been estimated for felsic volcanism across the entire LIP (0.3-1 x $10^{6} \mathrm{~km}^{3}$; Ukstins Peate et al. 2003). As such, Afro-Arabian volcanism could have released 250 to $750 \mathrm{Gt} \mathrm{S}$ and 1300 to $3600 \mathrm{Gt} \mathrm{Cl}$, amounts that are comparable at order-of-magnitude uncertainties to those for other LIPs such as the Deccan and Siberian traps (e.g. Black et al. 2012; Self et al. 2008). However, Afro-Arabian volcanism postdates the c. 34-33.7 Ma acme of progressive/stepwise plankton extinctions (Keller 2005; Pearson et al. 2008; Peters et al. 2013), which highlights that, although the total halogen effusion of the Afro-Arabian LIP may have been large enough to affect deleteriously the biosphere, the rate of effusion was below a threshold necessary to cause major disruptions in ecosystems. A temporally calibrated example is the Central Atlantic Magmatic Province where only the first ( $600 \mathrm{kyr}$ in duration) of four volcanic pulses can be linked to an extinction event and the three later pulses had little to no effect on the biosphere (Blackburn et al. 2013).

4.3. Silicic super eruptions. Our new data show that the Tana felsic eruptions were comparable to some of the largest explosive volcanic events in Earth history. These spanned 2-3 Myr as evident from ${ }^{40} \mathrm{Ar} /{ }^{39} \mathrm{Ar}$ plateau and single crystal ages and $\mathrm{Rb}-\mathrm{Sr}$ isochron ages on thick, widespread ignimbrites and tuffs elsewhere in Ethiopia, and on correlative tephra layers $2700 \mathrm{~km}$ distant in the Indian Ocean (Baker et al. 1996; Coulié et al. 2003; Ukstins Peate et al. 2003, 2008; Riisager et al. 2005). The timing of Oi-1 and the c. 31 Ma super eruptions is interesting (Fig. 7) but similar spikes in 0-isotopes occur episodically through the Eocene-Oligocene, which urges caution and consideration of that relationship as a coincidence rather than as a cause-and-effect, particularly given that the 
271 0-isotope profile through the short interval of Tana super eruptions exhibits jagged rises and falls not unlike those marking the several millions of years preceding and postdating

273 the super eruptions. As for the other isotopic proxies, they remain unperturbed by those 274 eruptions (Fig. 7). Perhaps this is unsurprising given that the mid-Oligocene eruption (c. $28 \mathrm{Ma}$ ) of the La Garita caldera that formed the Fish Canyon Tuff, the volumetrically largest well-constrained silicic super eruption known for the Phanerozoic (e.g. Wotzlaw et al. 2014), likewise does not coincide with a perturbation in the stable isotope data.

5. Conclusion. Mapping of our new age constraints onto the timeline for EoceneOligocene environmental change reveals that there is neither a synchronicity in the initiation of nor a consistency in the trend of the changes-in-slopes of marine isotopic compositions and atmospheric $\mathrm{CO}_{2}$ records from one volcanic event to another during the Afro-Arabian LIP. This reconfirms that Afro-Arabian LIP volcanism was seemingly ineffectual in causing significant deviation of the trajectory of climate change that had begun in the early Palaeogene. Unlike the $<1-2$ Myr timescales documented for the duration of other Phanerozoic LIPs, Afro-Arabian LIP volcanism was protracted and lacked the necessary and sufficient rates of effusion and volatile emission to influence global-scale environmental change. Further, assuming that the Tana super eruptions are typical of those at other times in Earth history, our data imply that the role of super eruptions in inducing Earth System change most likely has to be as part of an ensemble of environmental circumstances rather than as a solo act.

Acknowledgements. We thank the University of Addis Ababa and H Dibabe and the late Prof M Umer for logistical support, and Prof H Lamb and D Clewley, University of Aberystwyth, and D Herd, A Calder and A Mackie, University of St Andrews, for assistance. Dr N Atkinson at the NERC Isotope Geosciences Laboratory performed the U-Pb dating analyses. This work was supported by NERC Grants NE/D012996/1 and NER/B/S/2002/00540 and NIGFSC IP/1024/0508. Three anonymous reviewers helped improve this manuscript.

\section{References}

Abate, B., Koeberl, C., Buchanan, P.C., Körner, W. 1998. Petrography and geochemistry of basaltic and rhyodacitic rocks from Lake Tana and the Gimjabet-Kosober areas (North 
Armstrong McKay, D.I., Tyrell, T., Wilson, P.A., Foster, G.L. 2014. Estimating the impact of cryptic degassing of Large Igneous Provinces: a mid-Miocene case study. Earth and Planetary Science Letters 403, 254-262.

Ayalew, D., Barbey, P., Marty, B., Reisberg, L., Yirgu, G., Pik, R. 2002. Source, genesis and timing of giant ignimbrite deposits associated with Ethiopian continental flood basalts. Geoch. Cosmoch. Acta 66, 1429-1448.

Baker, J., Snee, L., Menzies, M. 1996. A brief Oligocene period of flood volcanism in Yemen: implications for the duration and rate of continental flood volcanism at the Afro-Arabian triple junction. Earth and Planetary Science Letters 138, 39-55.

Black, B.A., Elkins-Tanton, L.T., Rowe, M.C., Ukstins Peate, I. 2012. Magnitude and consequences of volatile release from the Siberian Traps. Earth and Planetary Science Letters 317-318, 363-373.

Blackburn, T.J., Olsen, P.E., Bowring, S.A., McLean, N.M., Kent, D.V., Puffer, J., McHone, G., Rasbuty, E.T., Et-Touhami, M. 2013. Zircon U-Pb geochronology links the end-Triassic Extinction with the Central Atlantic Magmatic Process. Science 340, 941-945.

Bond, D.P.G., Wignall, P.B. 2014. Large igneous provinces and mass extinctions an update, in Keller, G. and Kerr, A.C., eds. Volcanism, Impacts, and Mass Extinctions: Causes and Effects. Geol. Soc. Amer. Spec. Pap. 505, 29-55.

Brand, U., Pesenato, R., Came, R, Affek, H., Angiolini, L., Azmy, K., Farabegoli, E. 2012. The end-Permian mass extinction: a rapid volcanic $\mathrm{CO}_{2}$ and $\mathrm{CH}_{4}$-climatic catastrophe. Chemical Geology 322-323, 121-144.

Bryan, S.E., Ferrari, L. 2013. Large igneous provinces and silicic large igneous provinces: progress in understanding over the last 25 years. Geol. Soc. Amer. Bull. 125, 1053-1078.

Burgess, S., Bowring, S., Shen, S-Z. 2014. High-precision timeline for Earth's most severe extinction. Proceedings Nat. Acad. Sci. USA. 111, 3316-3321.

Chenet, A.L., Quidelleur, X., Fluteau, F., Courtillot, V., Bajpal, S. 2007. ${ }^{40} \mathrm{~K}-40 \mathrm{Ar}$ dating of the main Deccan large igneous province: further evidence of KTB age and short duration. Earth Planet. Sci. Lett. 263, 1-15.

Condon, D. J., Schoene, B., McLean, N., Bowring, S. A., Parrish, R. 2015. Metrology and traceability of U-Pb isotope dilution geochronology (EARTHTIME Tracer Calibration Part I): Geochimica et Cosmochimica Acta, doi:10.1016/j.gca.2015.05.026

Chorowicz, J., Collet, B., Bonavia, F.F., Mohr, P., Parrot, J.F., Korme, T. 1998. The Tana basin, Ethiopia: intra-plateau uplift, rifting and subsidence. Tectonophys. 295, 351-367.

Coulié, E., Quidelleur, X., Gillot, P-Y., Courtillot, V., Lefèvre, J-C., Chiesa, S. 2003. Comparative $\mathrm{K}-\mathrm{Ar}$ and $\mathrm{Ar} / \mathrm{Ar}$ dating of Ethiopian and Yemenite Oligocene volcanism: implications for timing and duration of the Ethiopian traps. Earth and Planetary Science Letters 206, 477-492. 
Coxall, H.K., Wilson, P.A., Pälike, H., Lear, C.H., Backman, J. 2005. Rapid stepwise onset of Antarctic glaciation and deeper calcite compensation depth in the Pacific Ocean. Nature 433, 53-57.

Cramer, B.S., Toggweiler, J.R., Wright, J.D., Katz, M.E., Miller, K.G. 2009. Ocean overturning since the Late Cretaceous: inferences from a new benthic foraminiferal isotope compilation. Paleoceanography 24, doi:10.1029/2008PA001683.

Dessert, C., Depré, B., Gaillardet, J., François, L.M., Allègre, C. 2003. Basalt weathering laws and impact of basalt weathering on the global carbon cycle. Chem. Geol. 202, 257273.

Hofmann, C., Courtillot, V., Féraud, G., Rochette, P., Yirgu, G., Ketefo, E., Pik, R. 1997. Timing of the Ethiopian flood basalt event and implications for plume birth and global change. Nature 389, 838-841.

Keller, G. 2005. Impacts, volcanism and mass extinction: random coincidence or cause and effect. Australian J. Earth Sci. 52, 725-757.

Kent, D.V., Muttoni, G. 2013. Modulation of Late Cretaceous and Cenozoic climate by variable drawdown of atmospheric $p \mathrm{CO}_{2}$ from weathering of basaltic provinces on continents drifting through the equatorial humid belt. Clim. Past 9, 524-546.

Lefebvre, V., Donnadieu, Y., Godderis, Y., Fluteau, F., Hubert-Theuo, F. 2013. Was the Antarctic deglaciation caused by a high degassing rate during the early Cenozoic. Earth and Planetary Science Letters 371-372, 203-211.

Mark, D.F., Gonzalez, S., Huddart, D., Bohnel, H. 2010. Dating of the Valsequillo volcanic deposits: Resolution of an ongoing controversy in Central Mexico. Journal of Human Evolution 58, 441-445.

Marshall, M.H., Lamb, H.F., Huws, D., Davies, S.J., Bates, R., Bloemendal, J., Boyle, J., Leng, M.J., Umer, M., Bryant, C. 2011. Late Pleistocene and Holocene drought events at Lake Tana, the source of the Blue Nile. Global and Planetary Change 78, 147-161.

McLean, N., Condon, D.J., Schoene, B., Bowring, S.A. 2015. Evaluating uncertainties in the calibration of isotopic reference materials and multi-element isotopic tracers (EARTHTIME Tracer Calibration Part II): Geochimica et Cosmochimica Acta, doi:10.1016/j.gca.2015.02.040

Miller, K.G., Wright, J.D., Fairbanks, R.G. 1991. Unlocking the Ice House: OligoceneMiocene oxygen isotopes, eustasy, and margin erosion. J. Geophys. Res. 96, 6829-6848.

Mohr, P. 1983. Ethiopian flood basalt province. Nature 303, 577-584.

Mohr, P., Zanettin, B. 1988. The Ethiopian flood basalt province, in. J.D. Macdougall (Ed) Continental Flood Basalts. Kluwer, Dordrecht, 63-110. 
Navarre-Sitchler, A., Brantley, S. 2007. Basalt weathering across scales. Earth Planet. Sci. Lett. 261, 321-334.

Pälike, H., Norris, R.D., Herrle, J.O., Wilson, P.A., Coxall, H.K., Lear, C.H., Shackleton, N.J., Triparti, A.K., Wade, B.S. 2006. The heartbeat of the Oligocene climate system. Science 324, 1894-1898.

410

Pagani, M., Huber, M., Liu, Z., Bohaty, S.M., Henderiks, J., Sijp, W., Krishnan, S., DeConto, R.M. 2011. The role of carbon dioxide during onset of Antarctic glaciation. Science 334, 1261-1264.

Pearson, P.N., McMillan, I.K., Wade, B.S., Jones, T.D., Coxall, H.K., Brown, P.R., Lear, C.H. 2008. Extinction and environmental change across the Eocene-Oligocene boundary in Tanzania. Geology 36, 179-182.

Peters, S.E., Kelly, D.C., Fraass, J. 2013. Oceanographic controls on the diversity and extinction of planktonic foraminifera. Nature 493, 398-01.

Pik, R., Deniel, C, Coulon, C, Yirgu, G., Hofmann, Ayalew, D. 1998. The northwestern Ethiopian Plateau flood basalts: classification and spatial distribution of magma types. J. Volcanology and Geothermal Research 81, 91-111.

Pik, R., Deniel, C, Coulon, C, Yirgu, Marty, B. 1999. Isotopic and trace element signatures of Ethiopian flood basalts: evidence for plume-lithosphere interactions. Geochim. Cosmoch. Acta 63, 2263-2279.

Riisager, P., Knight, K.B., Baker, J.A., Ukstins Peate, I., Al-Kasadi, M., Al-Subbary, A., Renne, P.R. 2005. Paleomagnetism and 40Ar/39Ar geochronology of Yemeni Oligocene volcanics: implications for timing and duration of Afro-Arabian traps and geometry of the Oligocene paleomagnetic field. Earth Planet. Sci. Lett. 237, 647-672.

Rochette, P., Tamrat, E., Féraud, Pik, R., Courtillot, V., Ketefo, E., Coulon, C., Hoffmann, C., Vandamme, D., Yirgu, G. 1998. Magnetostratigraphy and timing of the Oligocene Ethiopian traps. Earth Planet. Sci. Lett. 164, 497-510.

Self, S., Blake, S., Sharma, K., Widdowson, M., Sephton, S. 2008. Sulfur and chlorine in Late Cretaceous Deccan magmas and eruptive gas release. Science 319, 1654-1657.

Svensen, H., Planke, S., Polozov, A.G., Schmidbauer, N., Corfu, F., Podladchikov, Y.Y., Jamveit, B. 2009. Siberian gas venting and the end Permian mass extinction. Earth and Planetary Science Letters 277, 490-500.

Ukstins, I.A., Renne, P.R., Wolfenden, E., Baker, J., Ayalew, D., Menzies, M. 2002. Matching conjugate volcanic rifted margins: ${ }^{40} \mathrm{Ar} /{ }^{39} \mathrm{Ar}$ chronostratigraphy of pre- and syn-rift bimodal flood volcanism in Ethiopia and Yemen. Earth Planet. Sci. Lett. 198, 289-306.

Ukstins Peate, I., Baker, J.A., Kent, A.J.R., Al-Kadasi, M., Al-Subbary, A., Ayalew, D., Menzies, M. 2003. Correlation of Indian Ocean tephra to individual Oligocene silicic eruptions from the Afro-Arabian flood volcanism. Earth Planet. Sci. Lett. 211, 311-327. 
454 Ukstins Peate, I., Kent, A.J.R., Baker, J.A., Menzies, M.A. 2008. Extreme geochemical

455 heterogeneity in Afro-Arabian Oligocene tephras: preserving fractional crystallization

456 and mafic recharge processes in silicic magma chambers. Lithos 102, 260-278.

Westerhold, T., Rohl, U., Palike, H., Wilkens, R., Wilson, P.A., Acton, G. 2014. Orbitally 459 tuned timescale and astronomical forcing in the middle Eocene to early Oligocene.

460 Climate of the Past 10, 955-973.

461

462

463

464

Wolela, A. 2008. Sedimentation of the Triassic-Jurassic Adrigat Sandstone Formation, Blue Nile (Abay) Basin, Ethiopia. J. Afr. Earth Sci. 52, 30-42.

Wotzlaw, J-F., Schalteger, U., Frick, D.A., Dungan, M.A., Gerdes, A., Günther. 2014.

466 Tracking the evolution of large-volume silicic magma reservoirs from assembly to

467 supereruption. Geology 41, 867-870.

Yemane, K., Robert, C., Bonnefille, R. 1987. Pollen and clay mineral assemblages of a late Miocene lacustrine sequence from the Northwestern Ethiopian Highlands. Palaeogeography, Palaeoclimatology, Palaeoecology 60, 123-141.

Zachos, J.C., Dickens, G.R., Zeebe, R.E. 2008. An early Cenozoic perspective on 
Figure 1. Generalised Cenozoic geology of the regions bordering the Main Ethiopian Rift system (simplified from the Geological Map of Ethiopia). Circled ' $A$ ' is the location of Addis Ababa.

Figure 2. Simplified geological map of the Lake Tana region based on mapping done during this work.

Figure 3. Stratigraphy of the Lake Tana region showing the four map units and position of geochronology samples. See text for details and Supplementary Files for GPS locations of samples. m.a.s.l. - metres above sea level.

Figure 4. Felsic volcanic rocks. A. Rhyolite domes 10-20 km southeast of Kunzla (southwest corner of Lake Tana). B. Tilted rhyolite dome $5 \mathrm{~km}$ west of Gorgora (northcentral margin of Lake Tana); basal part consists of flow-banded rhyolite whereas inner part of dome consists of more massive rhyolite. C. Flow-banded rhyolite of sample Aby1 (northeast corner of Lake Tana) that yielded a U-Pb zircon age of 30.844 $\pm 0.027 / 0.046 \mathrm{Ma}$. $\mathbf{D}$ and $\mathbf{E}$. Massive ignimbrite flows and large bomb of pumiceous and banded rhyolite ( $\sim 12 \mathrm{~km}$ west of Yifag, northeast margin of Lake Tana). F and G. Fragmental texture of ignimbrite deposits; F contains a variety of felsic clasts and minor mafic clasts whereas $\mathrm{G}$ is mostly pumice (area west of Gorgora, north-central shoreline of Lake Tana). H. Cross-bedded volcaniclastic conglomerate-sandstone with obsidian and felsic volcanic clasts and rare basalt clasts; this unit overlies sharply the felsic tuff of sample Hydro-1 (15 km southwest of Kunzla) that yielded a U-Pb zircon age of 31.108 $\pm 0.020 / 0.041 \mathrm{Ma}$.

Figure 5. Structural features of the felsic unit. A. East-tilted fault blocks of silicic ignimbrite and tuff ( $\sim 5 \mathrm{~km}$ northwest of Kunzla, southwest margin of Lake Tana). B. Progressive onlap and burial of c. 31 Ma southwest-tilted felsitic rocks by flat-lying c. 24 Ma basalt ( $\sim 20 \mathrm{~km}$ south of Kunzla).

Figure 6. Seismic profile showing steep-sided bedrock margin beneath Lake Tana and how the sedimentary fill abuts against and buries those margins. The sediments are $>180 \mathrm{~m}$ thick (and likely much thicker) and linear extrapolation of the ${ }^{14} \mathrm{C}$ age for the topmost desiccation surface (Marshall et al. 2011) would imply that the base of the seismically imaged sediment is in excess of $150 \mathrm{ka}$.

Figure 7. Isotopic and atmospheric $\mathrm{CO}_{2}$ envelopes for the Cenozoic; grey and black shading denotes age brackets for volcanism in the Lake Tana and surrounding regions. C- and O-isotope envelopes are from Zachos et al. $(2001,2008)$ and other proposed best-fit solid lines are from Cramer et al. (2009). $\mathrm{CO}_{2}$ trends generalised from multiple proxies as reported by Pagani et al. (2011) and Zhang et al. (2013). Timescale 
Figure 1

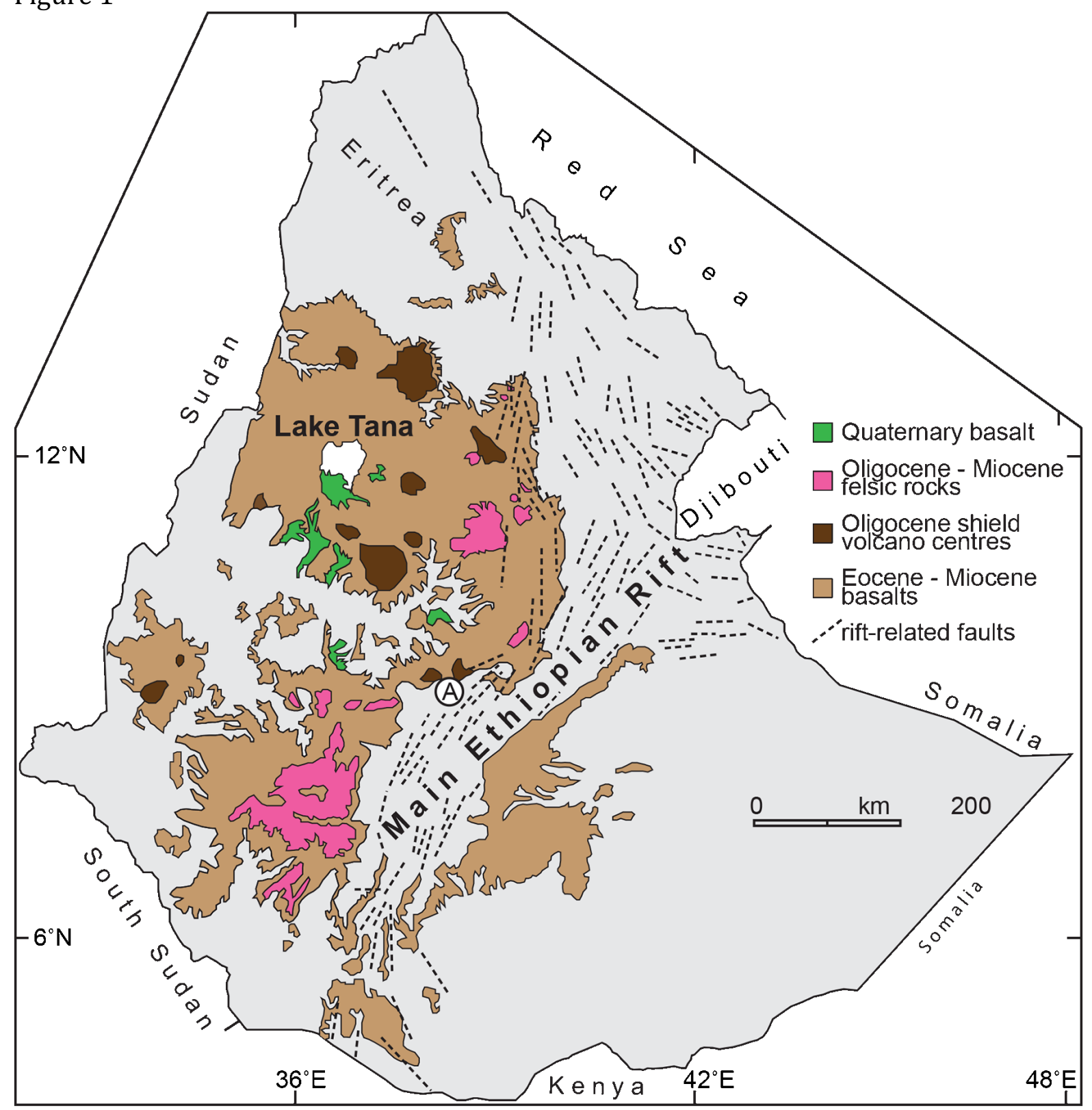


Figure 2.

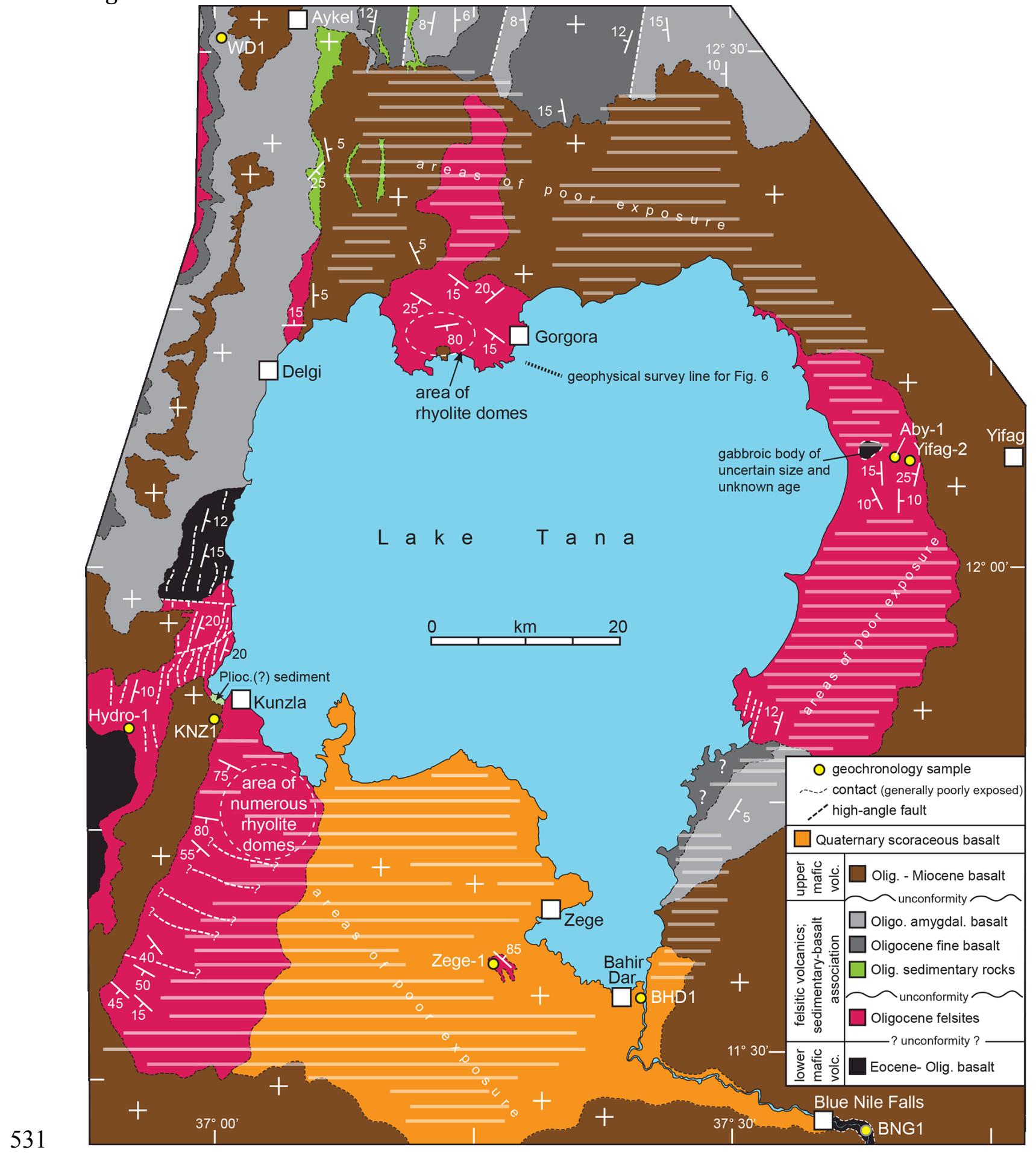

532 


\section{Lake Tana region stratigraphy}

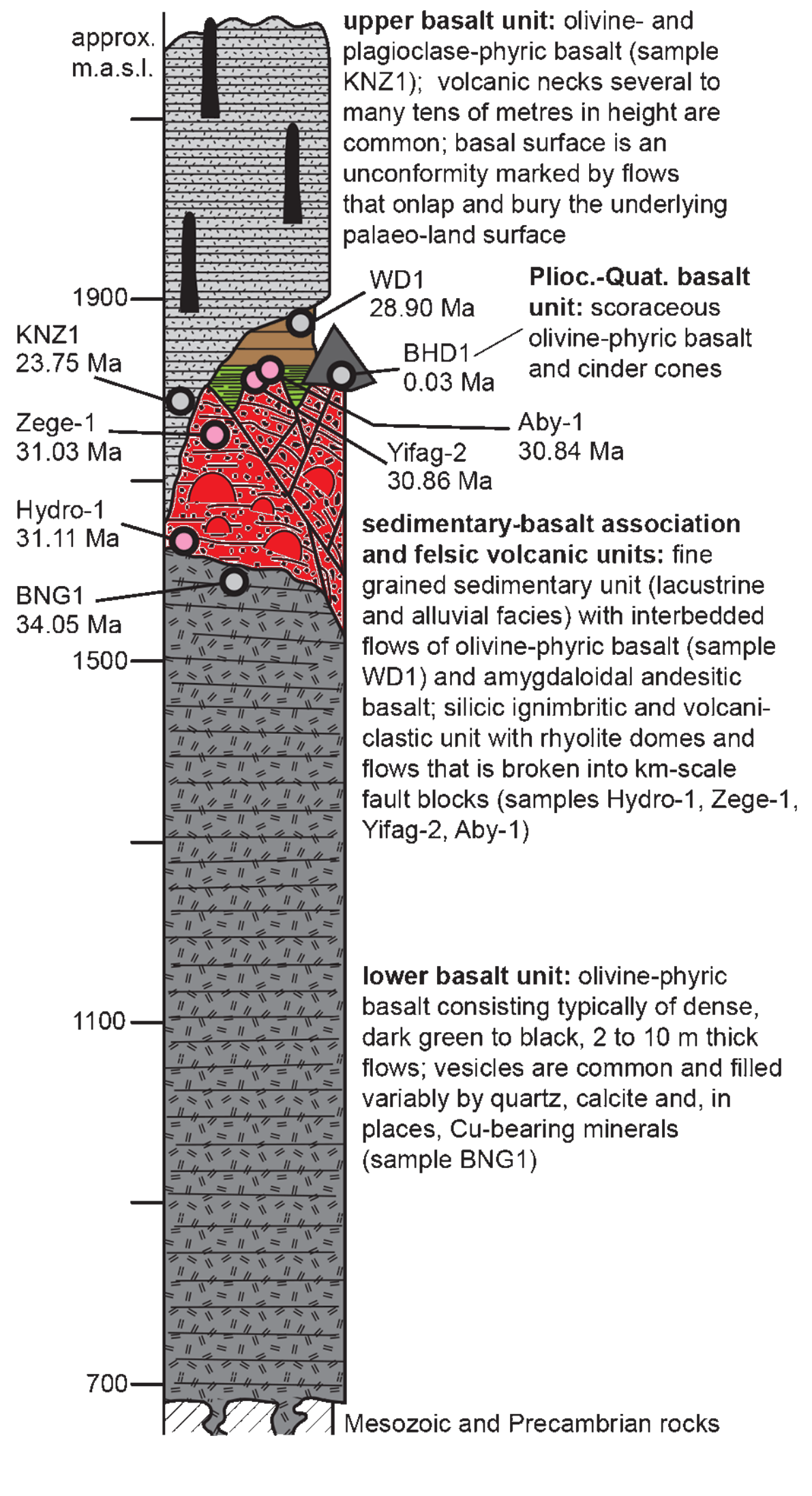


538 Figure 4.
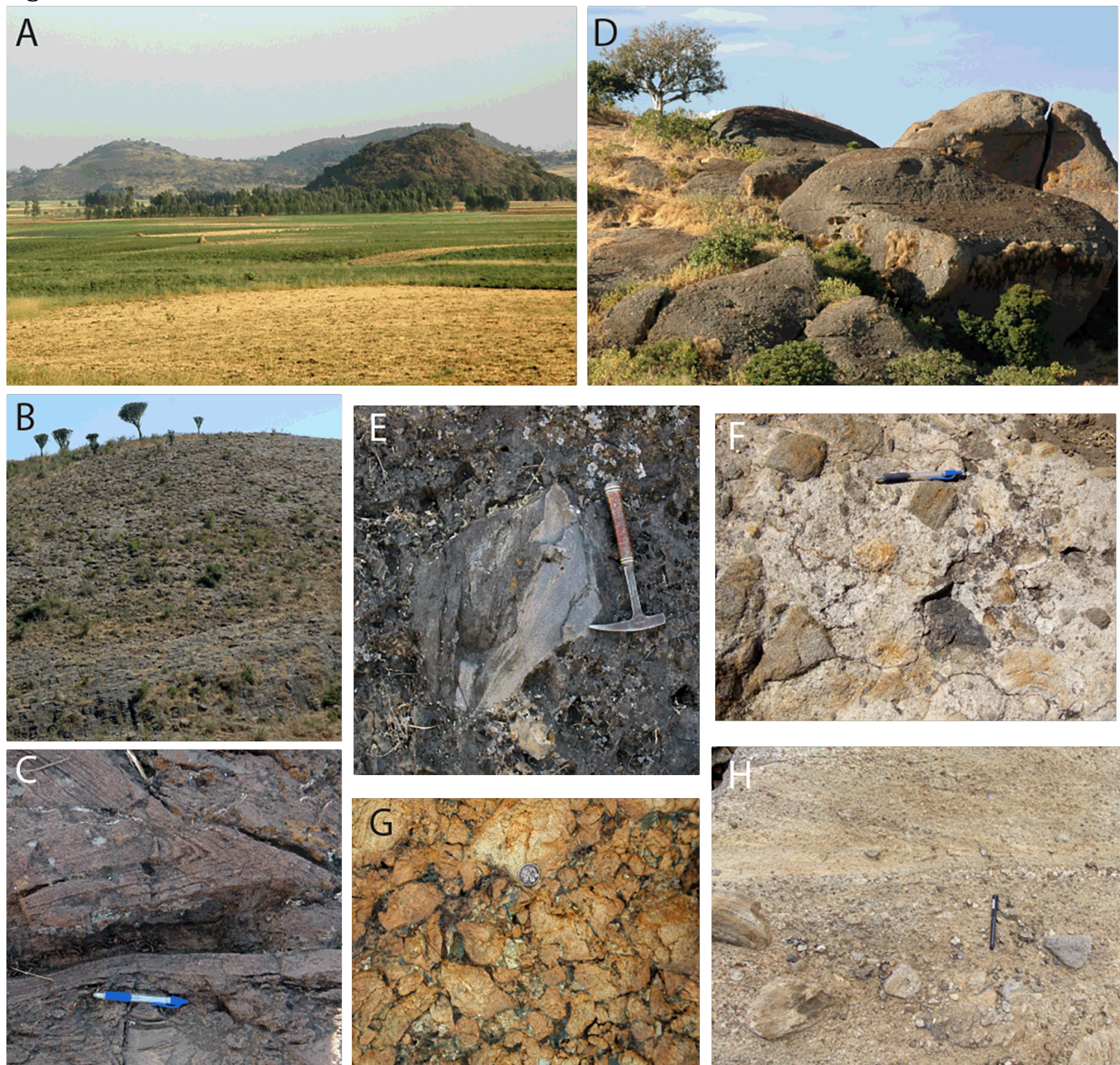

539
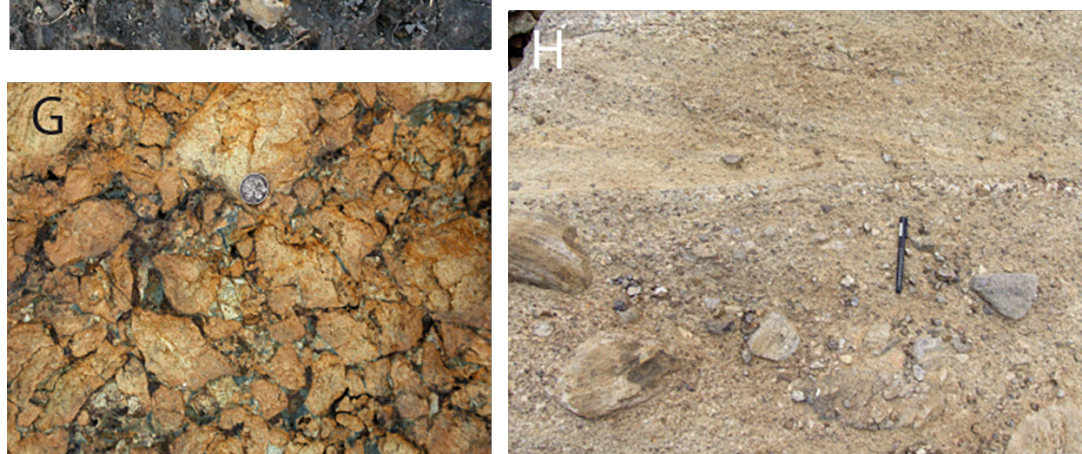

540

541 
542 Figure 5.

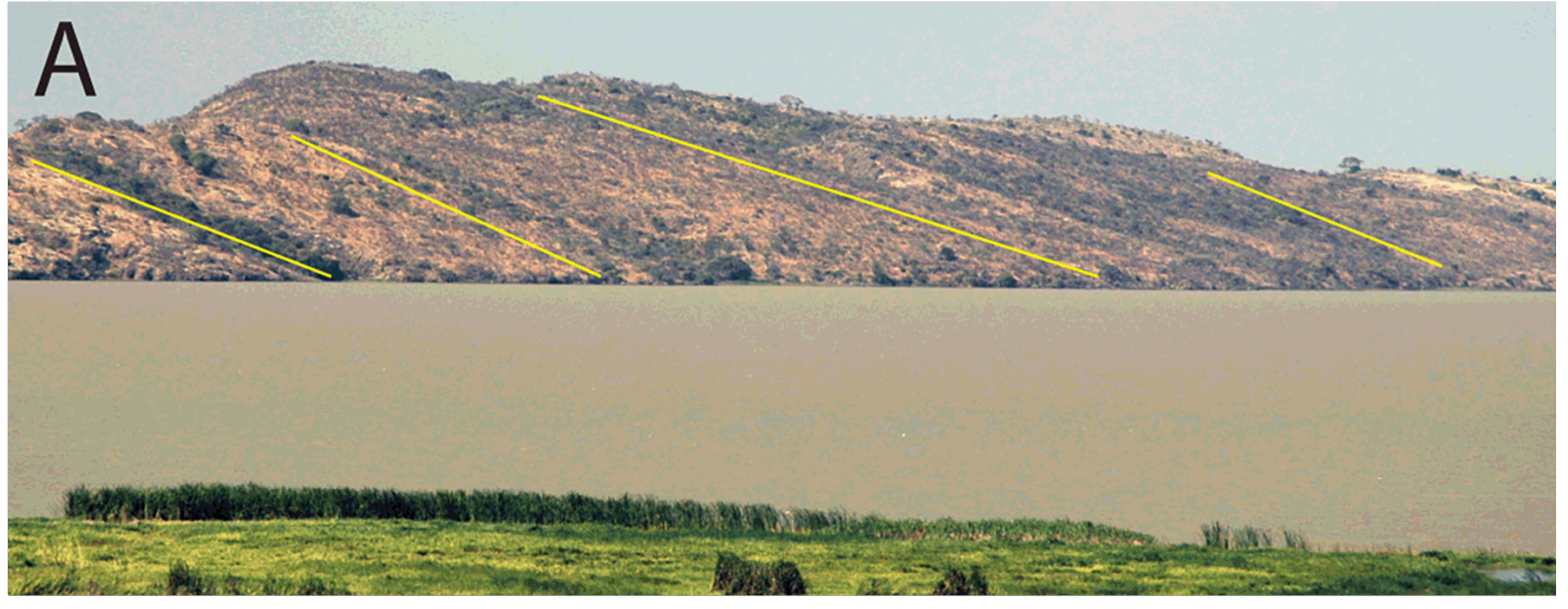

\section{B}

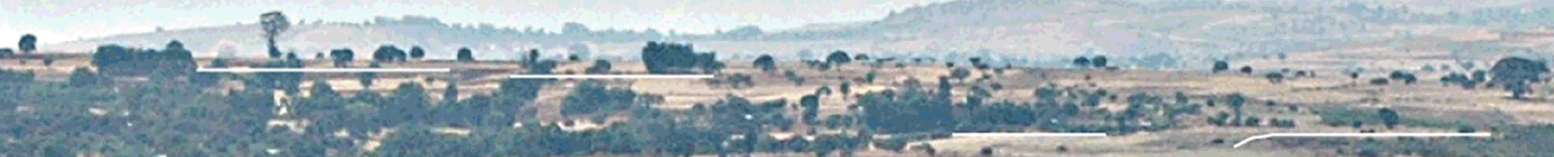

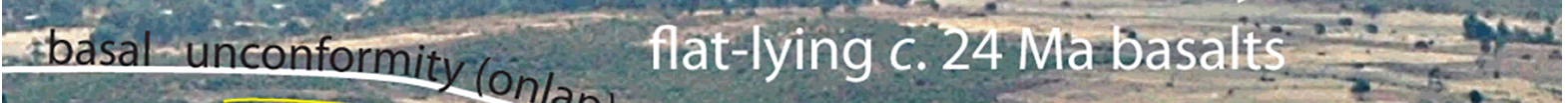

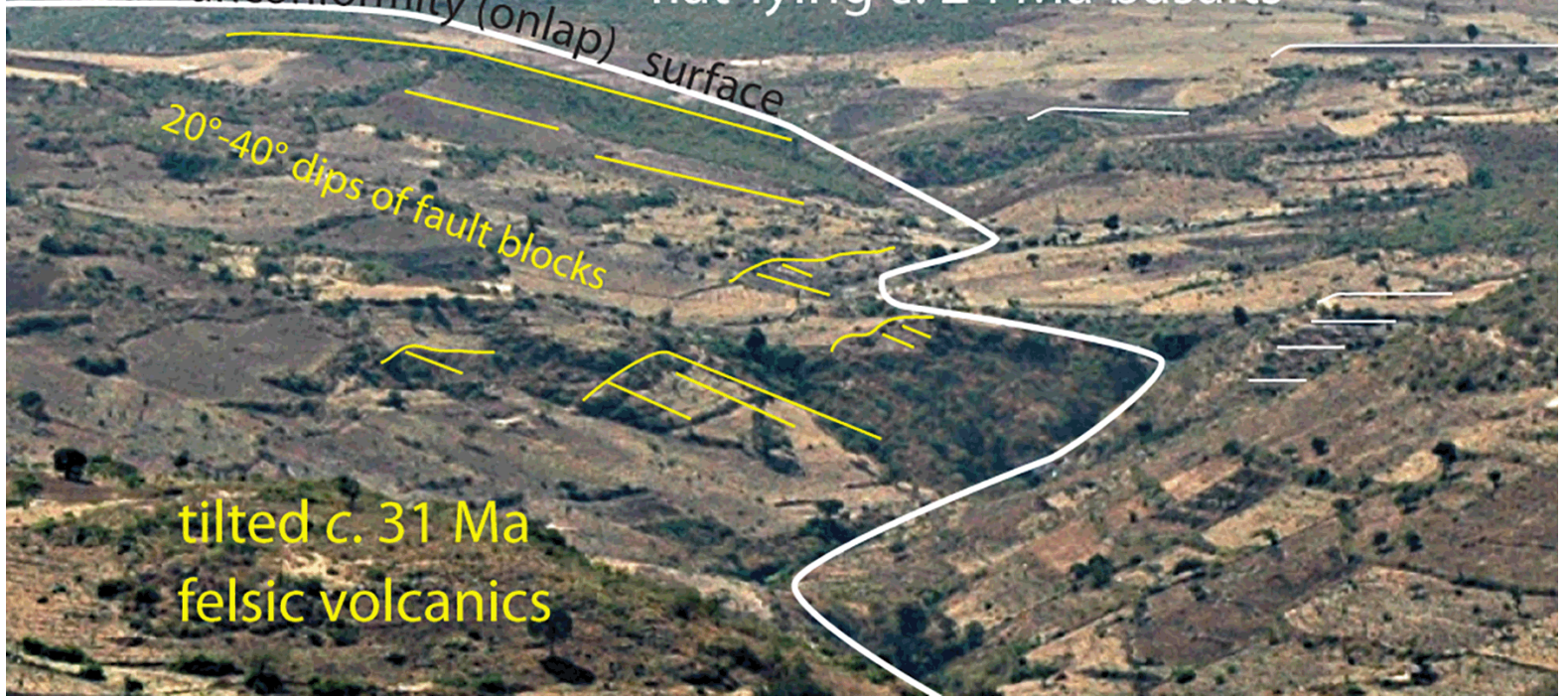


$546 \quad$ Figure 6.

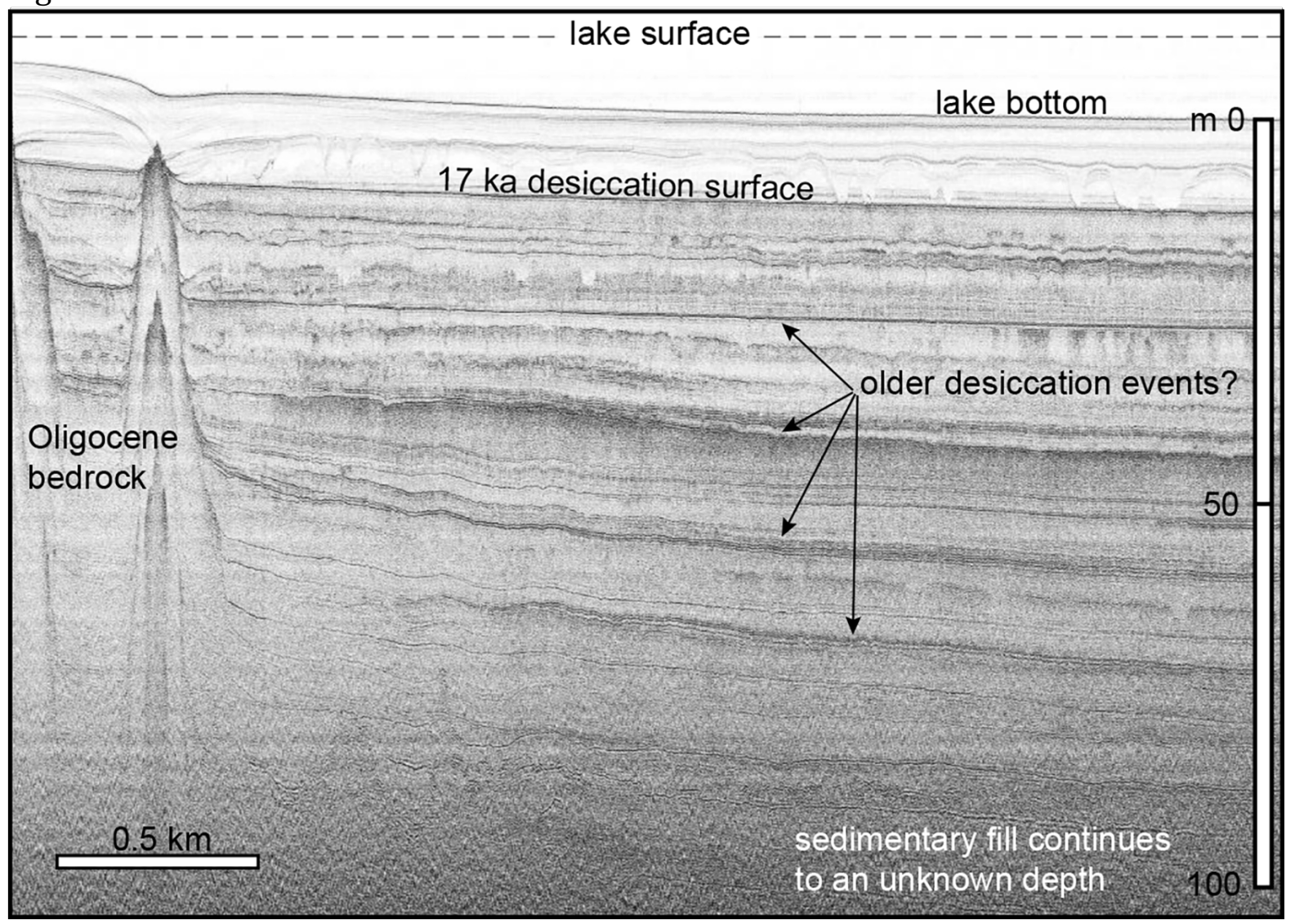

548

549 
Figure 7.

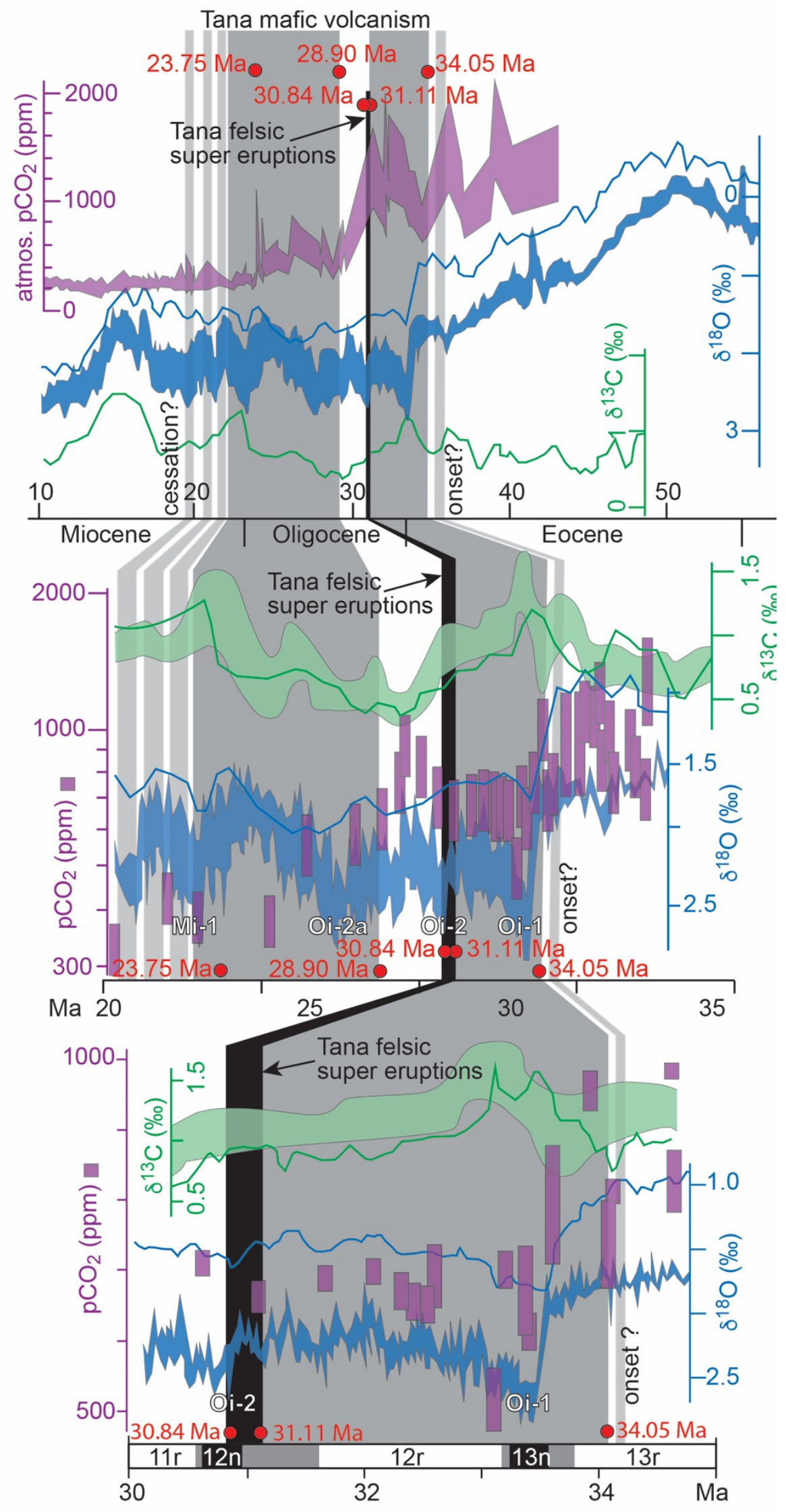

